Nippon Suisan Gakkaishi $\quad$ 75(2), 204-212 (2009)

\title{
北海道周辺海域におけるスルメイカの日齢と発生時期
}

\author{
坂口健司, ${ }^{*}$ 佐藤 $\quad$ 充, ${ }^{2}$ 三橋 正 基, ${ }^{1}$ 木 所 英 昭 ${ }^{3}$ \\ (2008 年 8 月 13 日受付, 2008 年 10 月 8 日) \\ ${ }^{1}$ 北海道立釧路水産試験場， ${ }^{2}$ 北海道立中央水産試験場, \\ 3 蛍水産総合研究センター日本海区水産研究所 \\ Age and hatching date of Japanese common squid, \\ Todarodes pacificus, in waters around Hokkaido

\section{KENJI SAKAGUCHI, ${ }^{*}{ }^{*}$ TORU SATO ${ }^{2}$ MASAKI MITSUHASHI ${ }^{1}$ AND HIDEAKI KIDOKORO ${ }^{3}$}

\begin{abstract}
${ }^{1}$ Hokkaido Kushiro Fisheries Experimental Station, Kushiro, Hokkaido 085-0024, ${ }^{2}$ Hokkaido Central Fisheries Experimental Station, Yoichi, Hokkaido 046-8555, 33apan Sea National Fisheries Research Institute, Fisheries Research Agency, Niigata 951-8121, Japan
\end{abstract}

\begin{abstract}
Statolith increment analysis was applied to 1,421 specimens of the Japanese common squid, Todarodes pacificus, to estimate the age and hatching date. Samples were collected during May-November in 2001 and 2002 in the waters around Hokkaido. Two hatching groups were observed in waters around Hokkaido: November- to December-hatched T. pacificus and February- to May-hatched T. pacificus. During May-September, November- and December-hatched squid predominated in the Sea of Japan off Hokkaido and in waters off southern Hokkaido. Squid that hatched in February-May were predominant in waters off southern Hokkaido and the Pacific coast off eastern Hokkaido during August-October, and during October-November in the Okhotsk coast off Hokkaido and the Sea of Japan off Hokkaido. It was found that between August and September, both hatching groups occurred in waters off southern Hokkaido.
\end{abstract}

キーワード：回遊, スルメイカ, 日歯, 発生時期, 分布, 平衡石, 北海道

スルメイカ Todarodes pacificus は日本周辺海域で広く 漁獲されており，北海道周辺海域では主要な漁業資源と して漁獲されている。スルメイカは寿命が約 1 年で, 主に秋の日本海南西部と冬の東シナ海で生まれると考え られている。1,2) 秋に日本海南西部で生まれたスルメイカ は主に対馬暖流に運ばれて日本海を, 冬に東シナ海で生 まれたスルメイカは主に黒潮と対馬暖流に運ばれてそれ ぞれ太平洋と日本海を北上する。1)成長しながら北上回 遊したスルメイカは, 北海道周辺海域にも多く来遊し, 津軽海峡, 宗谷海峡, 千島列島周辺海域を通じて, 日本 海, 太平洋, オホーツク海を相互に移動する。1,3,4) その ため, 北海道周辺海域に打けるスルメイカの漁況予測や 資源評価を行ううえで, 生まれた時期別にスルメイカの 分布回遊の特性を明らかにすることが重要な課題になっ ている。
スルメイカ資源は季節発生群別に生態的特徵が解明さ れてきた。その分布特性については秋生まれ群が主に日 本海の沖合域に, 冬生まれ群が日本列島周辺海域に広く 分布すると推定されてきた。1,2) しかし，スルメイカの資 源量が大きく変動したときに, 両発生群の変動が独立せ ずにほぼ同調していたことや，固有と考えられてきた両 発生群の体サイズや成熟の特徵が変化するなど, 従来の 考え方では説明できない現象がみられるようになっ た。 ${ }^{5}$ この原因の 1 つに発生時期の推定精度が低かった ことが指摘された。5)この問題を解決する方法として, スルメイカの平衡石に輪紋が 1 日 1 本ずつ形成される ことが確認され，6)この輪紋を計数して日齢を推定する 解析方法（以下，日周輪解析とする）が報告された。7) この解析手法を用いることで, スルメイカの発生日を直 接推定することができるため, より高い精度での発生群

* Tel : 81-154-23-6221. Fax : 81-154-23-6225. Email : sakaguchik@fishexp.pref.hokkaido.jp 
ごとの生活史や分布回遊の検証が始まった。8

北海道周辺海域に分布するスルメイカについては, 北 海道西部日本海（以下，道西日本海とする）の分布群が 秋〜冬発生群から冬〜春発生群に入れ替わり, ${ }^{9)}$ 北海道 東部オホーツク海（以下，道東オホーツク海とする）の 分布群が冬〜春発生群であることがわかってきた。10)し かし, 襟裳岬以東の北海道東部太平洋（以下, 道東太平 洋とする）抢よび襟裳岬以西の北海道南部太平洋から津 軽海峡周辺の海域（以下，道南海域とする）に分布する スルメイカを対象とした日周輪解析結果は, 断片的にわ ずかに報告されているのみである。11)このため, 漁況予 測に必要な各海域に分布するスルメイカの相互関係が日 周輪解析による発生時期の観点から検討されていない。 他のイカ類資源では, 日周輪解析を用いることで群構造 が明確になったことが報告されていることからも, ${ }^{12)}$ 北 海道周辺の全海域に分布するスルメイカの発生時期を明 らかにすることで, 発生時期と分布回遊の関係の再検討 が大きく進むと考えられる。このため, 本報告では北海 道周辺の全海域で採集したスルメイカの日周輪解析を行 い, 北海道周辺海域に分布するスルメイカの日齢と発生 時期を明らかにし，分布回遊との関係について検討する。

\section{試料および方法}

標本として，2001年および 2002 年の 5～11 月に北 海道周辺海域において, 北海道立水産試験場所属の試験 調査船おやしお丸 (178トン), 金星丸 (151トン), 北 辰丸 (216 トン), 北洋丸 (237トン), 山形県加茂水産 高校所属の実習船鳥海丸 (452 トン) および一般の漁船 によって, 釣り, 底びき網, 定置網によって漁獲された スルメイカを用いた（Table 1)。調査船と実習船からは 無作為に, 漁船からは銘柄別に標本を抽出した。各海域 の主漁期の漁獲物を代表するように，道西日本海では 6 〜 11 月に 28 回, 道南海域では 5 10 月に 12 回, 道東 太平洋では 8 10月に 10 回, 道東オホーツク海では 10〜11月に 12 回, 合計 62 回, 標本を採集した。同じ 日に同じ位置で採集したスルメイカを 1 つ標本とし て扱った。

得られた合計 62 標本 5,994 個体のスルメイカの外套 長を $1 \mathrm{~mm}$ 単位で測定し, 標本別に平均外套長を求め, $1 \mathrm{~cm}$ 単位の外套長組成を作った。漁船漁獲物が複数の 銘柄に分かれている場合は, 漁獲物全体を反映するよう に銘柄別の外套長組成を銘柄別漁獲箱数で重み付けして 合計し, 全体の外套長組成と平均外套長を求めた。外套 長を測定した各標本から 14 59 個体, 合計 1,421 個体 を抽出し, 日周輪解析用の標本とした。道西日本海と道 南海域の外套長測定標本の外套長組成には, 複数のモ一 ドがみられるものや範囲が比較的広いものがみられたた め, 体サイズの偏りを避けるために外套長組成の各階級
に含まれる個体数に比例するように日周輪解析標本を抽 出した。ただし, 日周輪解析の処理を失敗した個体と 1 個体のみとなった外套長階級の個体は, その後の解析か ら除いた。道東太平洋と道東オホーツク海の外套長測定 標本の外套長組成は単峰型で範囲が比較的せまくまとま っていたため, 外套長測定標本から無作為に日周輪解析 標本を抽出した。ただし, 漁船漁獲物では主要銘柄の外 套長測定標本から無作為に抽出した。

スルメイカから取り出した平衡石は以下の手順で日周 輪解析を行った。7,13) 平衡石を後部面が上になるように スライドグラスの上に接着剤で固定し, 実体顕微鏡下で 観察しながら耐水性紙やすりおよび酸化アルミニウム研 磨シートを用いて研磨した。倍率 100 倍の油浸対物レ ンズを用いた光学顕微鏡に, CCD カメラを取り付け, テレビモニター上で核から背丘部までの輪紋を計数し た。1 個体の輪紋の計数は 3 回以上とし, その平均值を 日齢とした。得られた日齢と漁獲日から発生日を逆算推 定した。

北海道周辺海域のスルメイカの発生時期を分布海域別 - 時期別に比較するため, 標本採集海域を道西日本海 $(\mathrm{JW})$, 道南海域 $(\mathrm{SH})$, 道東太平洋 $(\mathrm{PE})$, 道東才ホー ツク海 $(\mathrm{OH})$ の 4 海域に区分し, さらに採集年と時期 (5〜7月，8〜9 月， 10〜11月）で区分した（Fig. 1, Table 1)。それぞれの標本グループ名を採集海域・年・ 時期により「JW11, SH21, PE12, OH13」などとした (Table 1)。便宜的に, 日周輪解析を行った個体を標本 グループ別に一括して合計し, 外套長と発生時期の組成 を作った。

\section{結果}

外套長 各調査点の外套長測定標本と日周輪解析標本 の平均外套長を Table 2 に示した。道西日本海と道南海 域では, 外套長測定標本の標準偏差が $20 \mathrm{~mm}$ 以上のも のが 14 標本, そのうち $30 \mathrm{~mm}$ 以上のものが 3 標本み られ, 道東太平洋と道東オホーツク海の標本よりも大き なばらつきがみられた。外套長測定標本と日周輪解析標 本の平均外套長の差は 1 標本を除いてすべて $1 \mathrm{~cm}$ 未満 であったため, 日周輪解析標本は外套長測定標本をおお むね代表しているものとして扱った。

日周輪解析個体の採集海域と時期に基づく標本グルー プ別の外套長組成を Fig. 2 に示した。道西日本海にお けるスルメイカの体サイズの変化を外套長組成のモード でみると，6〜7月採集標本（JW11, JW21）では 18 $\mathrm{cm}$ と $20 \mathrm{~cm}$ であったものが, 8〜9月採集標本 (JW12, JW22) では $25 \mathrm{~cm}$ と $26 \mathrm{~cm}$ まで大きくなり, $10 １ 1$ 月採集標本（JW13, JW23）では $22 \mathrm{~cm}$ と 24 $\mathrm{cm}$ とやや小さくなった。2001年と 2002 年の同時期の 外套長組成のモードの差は $1 \sim 2 \mathrm{~cm}$ で, 採集時期を通 
Table 1 Dates and locations of Todarodes pacificus collection sites, and sampling gear, number of body-measured and age-determined specimens in the waters around Hokkaido, 2001 and 2002

\begin{tabular}{|c|c|c|c|c|c|c|c|c|}
\hline \multirow{2}{*}{$\begin{array}{l}\text { Sampling } \\
\text { area }\end{array}$} & \multirow{2}{*}{\multicolumn{2}{|c|}{ Sampling date }} & \multicolumn{2}{|c|}{ Location } & \multirow{2}{*}{$\underset{\text { gear }}{\text { Sampling }}$} & \multirow{2}{*}{$\begin{array}{l}\text { No. of measured } \\
\text { specimens }\end{array}$} & \multirow{2}{*}{$\begin{array}{l}\text { No. of aged } \\
\text { specimens }\end{array}$} & \multirow{2}{*}{$\begin{array}{l}\text { Sample } \\
\text { group }\end{array}$} \\
\hline & & & $\mathrm{N}$ & $\mathrm{E}$ & & & & \\
\hline \multirow{28}{*}{$\begin{array}{l}\text { Sea of Japan off Hokkaido } \\
\text { (JW) }\end{array}$} & Jun. 27 & 2001 & $43^{\circ} 00^{\prime}$ & $140^{\circ} 01^{\prime}$ & jig & 100 & 19 & JW11 \\
\hline & Jun. 28 & 2001 & $42^{\circ} 28^{\prime}$ & $139^{\circ} 37^{\prime}$ & jig & 100 & 18 & \\
\hline & Jul. 1 & 2001 & $43^{\circ} 30^{\prime}$ & $139^{\circ} 20^{\prime}$ & jig & 100 & 15 & \\
\hline & Jul. 3 & 2001 & $44^{\circ} 00^{\prime}$ & $141^{\circ} 01^{\prime}$ & jig & 100 & 17 & \\
\hline & Jul. 4 & 2001 & $43^{\circ} 30^{\prime}$ & $140^{\circ} 40^{\prime}$ & jig & 100 & 17 & \\
\hline & Aug. 29 & 2001 & $43^{\circ} 30^{\prime}$ & $140^{\circ} 00^{\prime}$ & jig & 100 & 23 & JW12 \\
\hline & Aug. 31 & 2001 & $44^{\circ} 31^{\prime}$ & $139^{\circ} 21^{\prime}$ & jig & 100 & 18 & \\
\hline & Sep. 3 & 2001 & $45^{\circ} 00^{\prime}$ & $140^{\circ} 11^{\prime}$ & jig & 99 & 19 & \\
\hline & Sep. 4 & 2001 & $45^{\circ} 40^{\prime}$ & $141^{\circ} 20^{\prime}$ & jig & 49 & 15 & \\
\hline & Sep. 5 & 2001 & $45^{\circ} 50^{\prime}$ & $140^{\circ} 00^{\prime}$ & jig & 50 & 18 & \\
\hline & Sep. 6 & 2001 & $45^{\circ} 34^{\prime}$ & $141^{\circ} 02^{\prime}$ & jig & 50 & 14 & \\
\hline & Sep. 18 & 2001 & $45^{\circ} 41^{\prime}$ & $141^{\circ} 06^{\prime}$ & jig* & 375 & 17 & \\
\hline & Oct. 5 & 2001 & $44^{\circ} 32^{\prime}$ & $139^{\circ} 48^{\prime}$ & jig* & 110 & 28 & JW13 \\
\hline & Oct. 15 & 2001 & $45^{\circ} 32^{\prime}$ & $141^{\circ} 00^{\prime}$ & jig* & 130 & 28 & \\
\hline & Oct. 24 & 2001 & $43^{\circ} 30^{\prime}$ & $140^{\circ} 01^{\prime}$ & jig & 100 & 18 & \\
\hline & Nov. 7 & 2001 & $43^{\circ} 30^{\prime}$ & $139^{\circ} 30^{\prime}$ & jig & 100 & 19 & \\
\hline & Nov. 8 & 2001 & $43^{\circ} 24^{\prime}$ & $140^{\circ} 45^{\prime}$ & jig & 100 & 15 & \\
\hline & Nov.21 & 2001 & $43^{\circ} 18^{\prime}$ & $140^{\circ} 40^{\prime}$ & jig & 100 & 28 & \\
\hline & Jun. 25 & 2002 & $43^{\circ} 30^{\prime}$ & $140^{\circ} 39^{\prime}$ & jig & 100 & 19 & JW21 \\
\hline & Jun. 26 & 2002 & $43^{\circ} 00^{\prime}$ & $140^{\circ} 00^{\prime}$ & jig & 100 & 18 & \\
\hline & Jun. 27 & 2002 & $42^{\circ} 30^{\prime}$ & $139^{\circ} 40^{\prime}$ & jig & 100 & 18 & \\
\hline & Jun. 29 & 2002 & $43^{\circ} 00^{\prime}$ & $138^{\circ} 40^{\prime}$ & jig & 100 & 18 & \\
\hline & Jul. 2 & 2002 & $45^{\circ} 40^{\prime}$ & $140^{\circ} 40^{\prime}$ & jig & 76 & 19 & \\
\hline & Jul. 3 & 2002 & $44^{\circ} 40^{\prime}$ & $141^{\circ} 00^{\prime}$ & jig & 71 & 17 & \\
\hline & Aug. 28 & 2002 & $43^{\circ} 32^{\prime}$ & $140^{\circ} 01^{\prime}$ & jig & 100 & 17 & JW22 \\
\hline & Aug. 30 & 2002 & $44^{\circ} 30^{\prime}$ & $139^{\circ} 24^{\prime}$ & jig & 100 & 18 & \\
\hline & Oct. 31 & 2002 & $43^{\circ} 30^{\prime}$ & $140^{\circ} 40^{\prime}$ & jig & 100 & 15 & JW23 \\
\hline & Nov. 21 & 2002 & $45^{\circ} 42^{\prime}$ & $141^{\circ} 07^{\prime}$ & trawl & 100 & 18 & \\
\hline \multirow{12}{*}{$\begin{array}{l}\text { Waters off southern } \\
\text { Hokkaido }(\mathrm{SH})\end{array}$} & May 28 & 2002 & $41^{\circ} 16^{\prime}$ & $139^{\circ} 51^{\prime}$ & jig & 100 & 18 & SH21 \\
\hline & May 29 & 2002 & $41^{\circ} 00^{\prime}$ & $139^{\circ} 00^{\prime}$ & jig & 100 & 17 & \\
\hline & May 31 & 2002 & $40^{\circ} 01^{\prime}$ & $139^{\circ} 00^{\prime}$ & jig & 100 & 20 & \\
\hline & Jun. 24 & 2002 & $41^{\circ} 39^{\prime}$ & $140^{\circ} 38^{\prime}$ & jig & 96 & 18 & \\
\hline & Jun. 25 & 2002 & $41^{\circ} 57^{\prime}$ & $141^{\circ} 19^{\prime}$ & jig & 24 & 19 & \\
\hline & Jun. 26 & 2002 & $41^{\circ} 54^{\prime}$ & $142^{\circ} 37^{\prime}$ & jig & 100 & 17 & \\
\hline & Jun. 27 & 2002 & $41^{\circ} 10^{\prime}$ & $141^{\circ} 30^{\prime}$ & jig & 50 & 16 & \\
\hline & Aug. 27 & 2002 & $42^{\circ} 01^{\prime}$ & $141^{\circ} 15^{\prime}$ & jig & 100 & 28 & SH22 \\
\hline & Aug. 28 & 2002 & $42^{\circ} 00^{\prime}$ & $142^{\circ} 35^{\prime}$ & jig & 100 & 29 & \\
\hline & Aug. 29 & 2002 & $41^{\circ} 45^{\prime}$ & $140^{\circ} 41^{\prime}$ & jig & 50 & 27 & \\
\hline & Sep. 26 & 2002 & $41^{\circ} 45^{\prime}$ & $140^{\circ} 41^{\prime}$ & jig & 61 & 26 & \\
\hline & Oct. 30 & 2002 & $42^{\circ} 14^{\prime}$ & $141^{\circ} 56^{\prime}$ & jig & 31 & 27 & $\mathrm{SH} 23$ \\
\hline \multirow{10}{*}{$\begin{array}{l}\text { Pacific coast off eastern } \\
\text { Hokkaido (PE) }\end{array}$} & Aug. 21 & 2001 & $42^{\circ} 26^{\prime}$ & $143^{\circ} 50^{\prime}$ & jig & 60 & 59 & PE12 \\
\hline & Aug. 22 & 2001 & $42^{\circ} 14^{\prime}$ & $143^{\circ} 40^{\prime}$ & jig & 60 & 58 & \\
\hline & Sep. 2 & 2001 & $41^{\circ} 30^{\prime}$ & $143^{\circ} 30^{\prime}$ & jig & 50 & 35 & \\
\hline & Sep. 27 & 2001 & $42^{\circ} 39^{\prime}$ & $144^{\circ} 04^{\prime}$ & jig & 33 & 32 & \\
\hline & Oct. 1 & 2001 & $42^{\circ} 52^{\prime}$ & $145^{\circ} 00^{\prime}$ & jig* & 189 & 31 & PE13 \\
\hline & Oct. 22 & 2001 & $42^{\circ} 50^{\prime}$ & $144^{\circ} 10^{\prime}$ & jig* & 200 & 40 & \\
\hline & Aug. 28 & 2002 & $42^{\circ} 59^{\prime}$ & $145^{\circ} 39^{\prime}$ & jig & 60 & 26 & PE22 \\
\hline & Aug. 29 & 2002 & $42^{\circ} 46^{\prime}$ & $144^{\circ} 12^{\prime}$ & jig & 27 & 19 & \\
\hline & Sep. 30 & 2002 & $42^{\circ} 50^{\prime}$ & $144^{\circ} 15^{\prime}$ & jig & 100 & 16 & \\
\hline & Oct. 15 & 2002 & $42^{\circ} 15^{\prime}$ & $144^{\circ} 24^{\prime}$ & jig & 100 & 16 & PE23 \\
\hline
\end{tabular}


Table 1 (Continued)

\begin{tabular}{|c|c|c|c|c|c|c|c|c|}
\hline \multirow{2}{*}{$\begin{array}{l}\text { Sampling } \\
\text { area }\end{array}$} & \multirow{2}{*}{\multicolumn{2}{|c|}{ Sampling date }} & \multicolumn{2}{|c|}{ Location } & \multirow{2}{*}{$\begin{array}{l}\text { Sampling } \\
\text { gear }\end{array}$} & \multirow{2}{*}{$\begin{array}{l}\text { No. of measured } \\
\text { specimens }\end{array}$} & \multirow{2}{*}{$\begin{array}{l}\text { No. of aged } \\
\text { specimens }\end{array}$} & \multirow{2}{*}{$\begin{array}{l}\text { Sample } \\
\text { group }\end{array}$} \\
\hline & & & $\mathrm{N}$ & $\mathrm{E}$ & & & & \\
\hline \multirow{12}{*}{$\begin{array}{l}\text { Okhotsk coast off } \\
\text { Hokkaido }(\mathrm{OH})\end{array}$} & Oct. 12 & 2001 & $44^{\circ} 20^{\prime}$ & $144^{\circ} 40^{\prime}$ & jig & 60 & 28 & OH13 \\
\hline & Oct. 16 & 2001 & $43^{\circ} 55^{\prime}$ & $145^{\circ} 13^{\prime}$ & jig & 60 & 45 & \\
\hline & Oct. 22 & 2001 & $44^{\circ} 45^{\prime}$ & $142^{\circ} 46^{\prime}$ & set net* & 158 & 19 & \\
\hline & Nov. 6 & 2001 & $44^{\circ} 05^{\prime}$ & $145^{\circ} 15^{\prime}$ & set net* & 114 & 40 & \\
\hline & Nov. 11 & 2001 & $44^{\circ} 50^{\prime}$ & $142^{\circ} 45^{\prime}$ & set net* & 161 & 18 & \\
\hline & Nov. 13 & 2001 & $44^{\circ} 20^{\prime}$ & $143^{\circ} 35^{\prime}$ & set net* & 47 & 22 & \\
\hline & Nov. 19 & 2001 & $44^{\circ} 59^{\prime}$ & $142^{\circ} 52^{\prime}$ & trawl & 49 & 17 & \\
\hline & Nov. 19 & 2001 & $44^{\circ} 25^{\prime}$ & $143^{\circ} 45^{\prime}$ & trawl ${ }^{*}$ & 100 & 36 & \\
\hline & Oct. 15 & 2002 & $44^{\circ} 06^{\prime}$ & $145^{\circ} 16^{\prime}$ & set net* & 176 & 18 & $\mathrm{OH} 23$ \\
\hline & Oct. 18 & 2002 & $44^{\circ} 25^{\prime}$ & $143^{\circ} 55^{\prime}$ & trawl* & 100 & 24 & \\
\hline & Nov. 23 & 2002 & $45^{\circ} 05^{\prime}$ & $142^{\circ} 35^{\prime}$ & set net* & 80 & 20 & \\
\hline & Nov. 23 & 2002 & $44^{\circ} 06^{\prime}$ & $145^{\circ} 16^{\prime}$ & set net* & 188 & 17 & \\
\hline Total & & & & & & 5,994 & 1,421 & \\
\hline
\end{tabular}

* Sampling by commercial fishing boat.

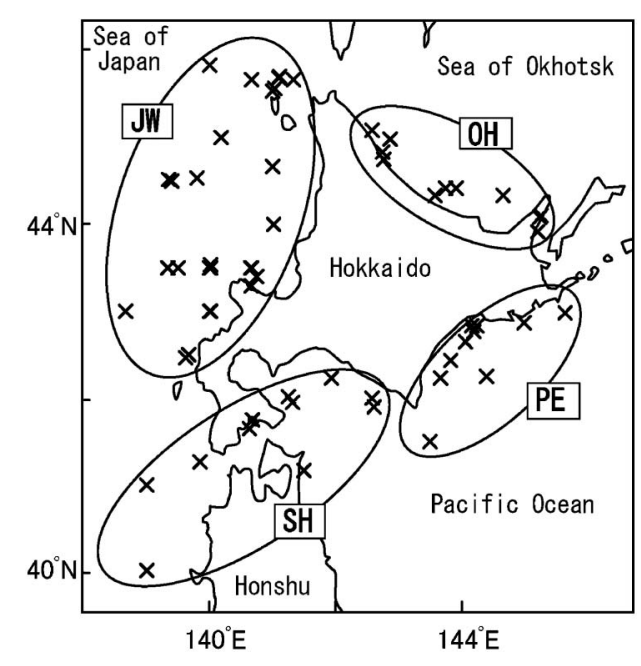

Fig. 1 Map of Hokkaido and northern Honshu, Japan showing the sampling stations $(x)$ and sampling areas (see Table 1) of Todarodes pacificus.

\section{じて一定の傾向はなかった。}

道南海域で採集し, 日周輪解析に用いたスルメイカの 外套長組成は，5～6月採集標本（SH21）ではすべて $21 \mathrm{~cm}$ 以下であったが，8９月採集標本（SH22）では モードが $21 \sim 24 \mathrm{~cm}$ まで大きくなり，10月採集標本 （SH23）では範囲が 19〜28 cm とばらつきが大きくな った。

道東太平洋のスルメイカの外套長組成は，8～9 月採 集標本（PE12, PE22）ではモードが $19 \mathrm{~cm}$ と $21 \mathrm{~cm}$ に みられ，10 月採集標本 (PE13, PE23) ではモードが $23 \mathrm{~cm}$ と $24 \mathrm{~cm}$ にみられ，23〜 $25 \mathrm{~cm}$ が約 $75 \%$ を占め た。同時期の外套長組成のモードを年別で比較すると, 2001 年の方が 2002 年より $1 \sim 2 \mathrm{~cm}$ 大きかった。
道東オホーツク海の $10 \sim 11$ 月採集標本（OH13, OH23）の外套長組成は, 2001 年と 2002 年で良く似て 抢り，22〜24 cm が多かった。この外套長組成の形や モードは, 道東太平洋の 10 月採集標本とも似ていた。 2001 年の方が 2002 年よりも外套長組成のモードが 1 $\mathrm{cm}$ 大きかった。

日齢 スルメイカの標本別の平均日齢を Table 2 に示 した。道西日本海で 2001 2002 年に採集したスルメイ 力の平均日齢は, 6 7 月採集標本 (JW11, JW21) が 202 235 日と最も若齢で，8～9 月採集標本（JW12， JW22）が 250〜278 日と最も高齢になり，10〜11月採 集標本（JW13, JW23）は 220～267 日とやや若齢にも ぞった。10１1月採集標本では日齢の標準偏差が 23〜 42 日であり，9月以前に比べてばらつきが大きくなっ た。

道南海域のスルメイカの平均日齢は，5～6 月採集標 本（SH21）が 192 210 日と比較的若齢で, 標準偏差 が 16 日以下と比較的小さかったが， 8 月以降（SH22, SH23）では平均日齢が 216〜234 日と高齢になり, 標 準偏差が 29〜40 mm と大きくなった。

道東太平洋のスルメイカの平均日齢は, 8 9 月採集 標本（PE12, PE22）が 183 209 日であったが，10月 採集標本（PE13, PE23）では202〜210日であった。 年別の比較では, 8〜9月採集標本で 2001 年の方が 2002 年よりもやや高齢であった。

道東オホーック海で $10 \sim 11$ 月に採集した標本 (OH13, OH23) の平均日齢は 193〜220 日であった。

発生時期 日周輪解析個体の採集海域と時期に基づく 標本グループ別の発生時期の組成を Fig. 3 に示した。 道西日本海で 2001 2002 年に採集したスルメイカの主 な発生時期は，6〜 7 月採集標本 (JW11, JW21) が 11 
Table 2 Mean mantle length ( $\mathrm{mm}$ ) and age (days) of Todarodes pacificus at each sampling date collected in the waters around Hokkaido, 2001 and 2002

\begin{tabular}{|c|c|c|c|c|c|}
\hline \multirow{2}{*}{$\begin{array}{l}\text { Sample group } \\
\text { JW11 }\end{array}$} & \multirow{2}{*}{\multicolumn{2}{|c|}{ Sampling date }} & \multicolumn{2}{|c|}{ Mantle length (mean \pm s.d.) } & \multirow{2}{*}{$\begin{array}{c}\text { age }(\text { mean } \pm \text { s.d. }) \\
219 \pm 13\end{array}$} \\
\hline & & & $\begin{array}{c}\text { measured specimens } \\
216 \pm 20\end{array}$ & $\begin{array}{c}\text { aged specimens } \\
213 \pm 18\end{array}$ & \\
\hline JW11 & $\begin{array}{l}\text { Jun. } 27 \\
\text { Jun. } 28 \\
\text { Jul. } 1 \\
\text { Jul. } 3 \\
\text { Jul. } 4\end{array}$ & $\begin{array}{l}2001 \\
2001 \\
2001 \\
2001 \\
2001\end{array}$ & $\begin{array}{l}216 \pm 20 \\
218 \pm 19 \\
230 \pm 17 \\
202 \pm 15 \\
199 \pm 20\end{array}$ & $\begin{array}{l}213 \pm 18 \\
220 \pm 16 \\
231 \pm 10 \\
200 \pm 11 \\
198 \pm 17\end{array}$ & $\begin{array}{l}219 \pm 13 \\
230 \pm 17 \\
235 \pm 14 \\
219 \pm 14 \\
217 \pm 17\end{array}$ \\
\hline JW12 & $\begin{array}{l}\text { Aug. } 29 \\
\text { Aug. } 31 \\
\text { Sep. } 3 \\
\text { Sep. } 4 \\
\text { Sep. } 5 \\
\text { Sep. } 6 \\
\text { Sep. } 18\end{array}$ & $\begin{array}{l}2001 \\
2001 \\
2001 \\
2001 \\
2001 \\
2001 \\
2001\end{array}$ & $\begin{array}{l}244 \pm 24 \\
264 \pm 18 \\
249 \pm 17 \\
245 \pm 24 \\
248 \pm 19 \\
238 \pm 35 \\
243 \pm 26\end{array}$ & $\begin{array}{l}241 \pm 18 \\
265 \pm 15 \\
247 \pm 15 \\
245 \pm 20 \\
245 \pm 14 \\
243 \pm 29 \\
251 \pm 10\end{array}$ & $\begin{array}{l}266 \pm 24 \\
278 \pm 15 \\
271 \pm 15 \\
250 \pm 20 \\
263 \pm 18 \\
260 \pm 23 \\
259 \pm 20\end{array}$ \\
\hline JW13 & $\begin{array}{l}\text { Oct. } 5 \\
\text { Oct. } 15 \\
\text { Oct. } 24 \\
\text { Nov. } 7 \\
\text { Nov. } 8 \\
\text { Nov. } 21\end{array}$ & $\begin{array}{l}2001 \\
2001 \\
2001 \\
2001 \\
2001 \\
2001\end{array}$ & $\begin{array}{l}239 \pm 20 \\
234 \pm 19 \\
234 \pm 17 \\
244 \pm 14 \\
234 \pm 20 \\
221 \pm 23\end{array}$ & $\begin{array}{l}243 \pm 11 \\
236 \pm 11 \\
231 \pm 16 \\
246 \pm 12 \\
238 \pm 11 \\
219 \pm 22\end{array}$ & $\begin{array}{l}248 \pm 32 \\
231 \pm 23 \\
239 \pm 31 \\
252 \pm 36 \\
267 \pm 30 \\
223 \pm 35\end{array}$ \\
\hline JW21 & $\begin{array}{l}\text { Jun. } 25 \\
\text { Jun. } 26 \\
\text { Jun. } 27 \\
\text { Jun. } 29 \\
\text { Jul. } 2 \\
\text { Jul. } 3 \\
\end{array}$ & $\begin{array}{l}2002 \\
2002 \\
2002 \\
2002 \\
2002 \\
2002\end{array}$ & $\begin{array}{l}176 \pm 11 \\
205 \pm 19 \\
200 \pm 17 \\
225 \pm 18 \\
182 \pm 11 \\
187 \pm 16\end{array}$ & $\begin{array}{l}176 \pm 9 \\
204 \pm 12 \\
201 \pm 14 \\
227 \pm 14 \\
181 \pm 9 \\
188 \pm 15\end{array}$ & $\begin{array}{l}202 \pm 11 \\
206 \pm 8 \\
212 \pm 15 \\
225 \pm 15 \\
214 \pm 13 \\
220 \pm 11\end{array}$ \\
\hline JW22 & $\begin{array}{l}\text { Aug. } 28 \\
\text { Aug. } 30\end{array}$ & $\begin{array}{l}2002 \\
2002\end{array}$ & $\begin{array}{l}241 \pm 28 \\
266 \pm 15\end{array}$ & $\begin{array}{l}234 \pm 21 \\
264 \pm 12\end{array}$ & $\begin{array}{l}264 \pm 15 \\
260 \pm 19\end{array}$ \\
\hline JW23 & $\begin{array}{l}\text { Oct. } 31 \\
\text { Nov. } 21\end{array}$ & $\begin{array}{l}2002 \\
2002\end{array}$ & $\begin{array}{l}228 \pm 20 \\
230 \pm 24\end{array}$ & $\begin{array}{l}230 \pm 15 \\
233 \pm 12\end{array}$ & $\begin{array}{l}242 \pm 42 \\
220 \pm 33\end{array}$ \\
\hline $\mathrm{SH} 21$ & $\begin{array}{l}\text { May } 28 \\
\text { May } 29 \\
\text { May } 31 \\
\text { Jun. } 24 \\
\text { Jun. 25 } \\
\text { Jun. 26 } \\
\text { Jun. 27 }\end{array}$ & $\begin{array}{l}2002 \\
2002 \\
2002 \\
2002 \\
2002 \\
2002 \\
2002\end{array}$ & $\begin{array}{l}165 \pm 11 \\
178 \pm 10 \\
190 \pm 12 \\
172 \pm 15 \\
158 \pm 8 \\
165 \pm 12 \\
167 \pm 15\end{array}$ & $\begin{array}{l}168 \pm 10 \\
176 \pm 7 \\
186 \pm 9 \\
172 \pm 12 \\
157 \pm 5 \\
168 \pm 8 \\
166 \pm 10\end{array}$ & $\begin{array}{l}192 \pm 9 \\
195 \pm 10 \\
199 \pm 11 \\
207 \pm 14 \\
204 \pm 10 \\
205 \pm 16 \\
210 \pm 11\end{array}$ \\
\hline $\mathrm{SH} 22$ & $\begin{array}{l}\text { Aug. } 27 \\
\text { Aug. } 28 \\
\text { Aug. } 29 \\
\text { Sep. } 26\end{array}$ & $\begin{array}{l}2002 \\
2002 \\
2002 \\
2002\end{array}$ & $\begin{array}{l}220 \pm 14 \\
219 \pm 12 \\
247 \pm 14 \\
238 \pm 35\end{array}$ & $\begin{array}{l}222 \pm 11 \\
220 \pm 11 \\
249 \pm 10 \\
250 \pm 20\end{array}$ & $\begin{array}{l}216 \pm 33 \\
228 \pm 37 \\
231 \pm 32 \\
234 \pm 29\end{array}$ \\
\hline $\mathrm{SH} 23$ & Oct. 30 & 2002 & $237 \pm 32$ & $244 \pm 26$ & $228 \pm 40$ \\
\hline PE12 & $\begin{array}{l}\text { Aug. } 21 \\
\text { Aug. } 22 \\
\text { Sep. } 2 \\
\text { Sep. } 27\end{array}$ & $\begin{array}{l}2001 \\
2001 \\
2001 \\
2001 \\
\end{array}$ & $\begin{array}{l}219 \pm 16 \\
216 \pm 16 \\
220 \pm 19 \\
235 \pm 14\end{array}$ & $\begin{array}{l}220 \pm 16 \\
216 \pm 16 \\
214 \pm 8 \\
235 \pm 15\end{array}$ & $\begin{array}{l}200 \pm 20 \\
201 \pm 19 \\
209 \pm 20 \\
209 \pm 20\end{array}$ \\
\hline PE13 & $\begin{array}{l}\text { Oct. } 1 \\
\text { Oct. } 22\end{array}$ & $\begin{array}{l}2001 \\
2001\end{array}$ & $\begin{array}{l}241 \pm 13 \\
240 \pm 15\end{array}$ & $\begin{array}{l}240 \pm 6 \\
244 \pm 16\end{array}$ & $\begin{array}{l}206 \pm 18 \\
210 \pm 20\end{array}$ \\
\hline PE22 & $\begin{array}{l}\text { Aug. } 28 \\
\text { Aug. } 29 \\
\text { Sep. } 30\end{array}$ & $\begin{array}{l}2002 \\
2002 \\
2002\end{array}$ & $\begin{array}{l}202 \pm 15 \\
222 \pm 23 \\
237 \pm 19\end{array}$ & $\begin{array}{l}199 \pm 10 \\
217 \pm 17 \\
237 \pm 10\end{array}$ & $\begin{array}{l}183 \pm 15 \\
193 \pm 15 \\
195 \pm 10\end{array}$ \\
\hline PE23 & Oct. 15 & 2002 & $236 \pm 17$ & $232 \pm 8$ & $202 \pm 12$ \\
\hline $\mathrm{OH} 13$ & $\begin{array}{l}\text { Oct. } 12 \\
\text { Oct. } 16 \\
\text { Oct. } 22 \\
\text { Nov. } 6 \\
\text { Nov. } 11 \\
\text { Nov. } 13 \\
\text { Nov. } 19 \\
\text { Nov. } 19\end{array}$ & $\begin{array}{l}2001 \\
2001 \\
2001 \\
2001 \\
2001 \\
2001 \\
2001 \\
2001 \\
\end{array}$ & $\begin{array}{l}232 \pm 10 \\
232 \pm 25 \\
230 \pm 12 \\
235 \pm 11 \\
230 \pm 13 \\
234 \pm 17 \\
237 \pm 21 \\
236 \pm 17\end{array}$ & $\begin{array}{l}230 \pm 10 \\
232 \pm 28 \\
228 \pm 9 \\
233 \pm 10 \\
230 \pm 8 \\
237 \pm 15 \\
235 \pm 10 \\
229 \pm 5\end{array}$ & $\begin{array}{l}210 \pm 9 \\
201 \pm 20 \\
210 \pm 14 \\
216 \pm 13 \\
218 \pm 19 \\
211 \pm 18 \\
217 \pm 15 \\
217 \pm 13\end{array}$ \\
\hline $\mathrm{OH} 23$ & $\begin{array}{l}\text { Oct. } 15 \\
\text { Oct. } 18 \\
\text { Nov. } 23 \\
\text { Nov. } 23\end{array}$ & $\begin{array}{l}2002 \\
2002 \\
2002 \\
2002\end{array}$ & $\begin{array}{l}226 \pm 11 \\
227 \pm 11 \\
228 \pm 11 \\
228 \pm 15\end{array}$ & $\begin{array}{l}229 \pm 5 \\
227 \pm 9 \\
229 \pm 9 \\
228 \pm 5\end{array}$ & $\begin{array}{l}193 \pm 15 \\
197 \pm 18 \\
220 \pm 20 \\
211 \pm 12\end{array}$ \\
\hline
\end{tabular}



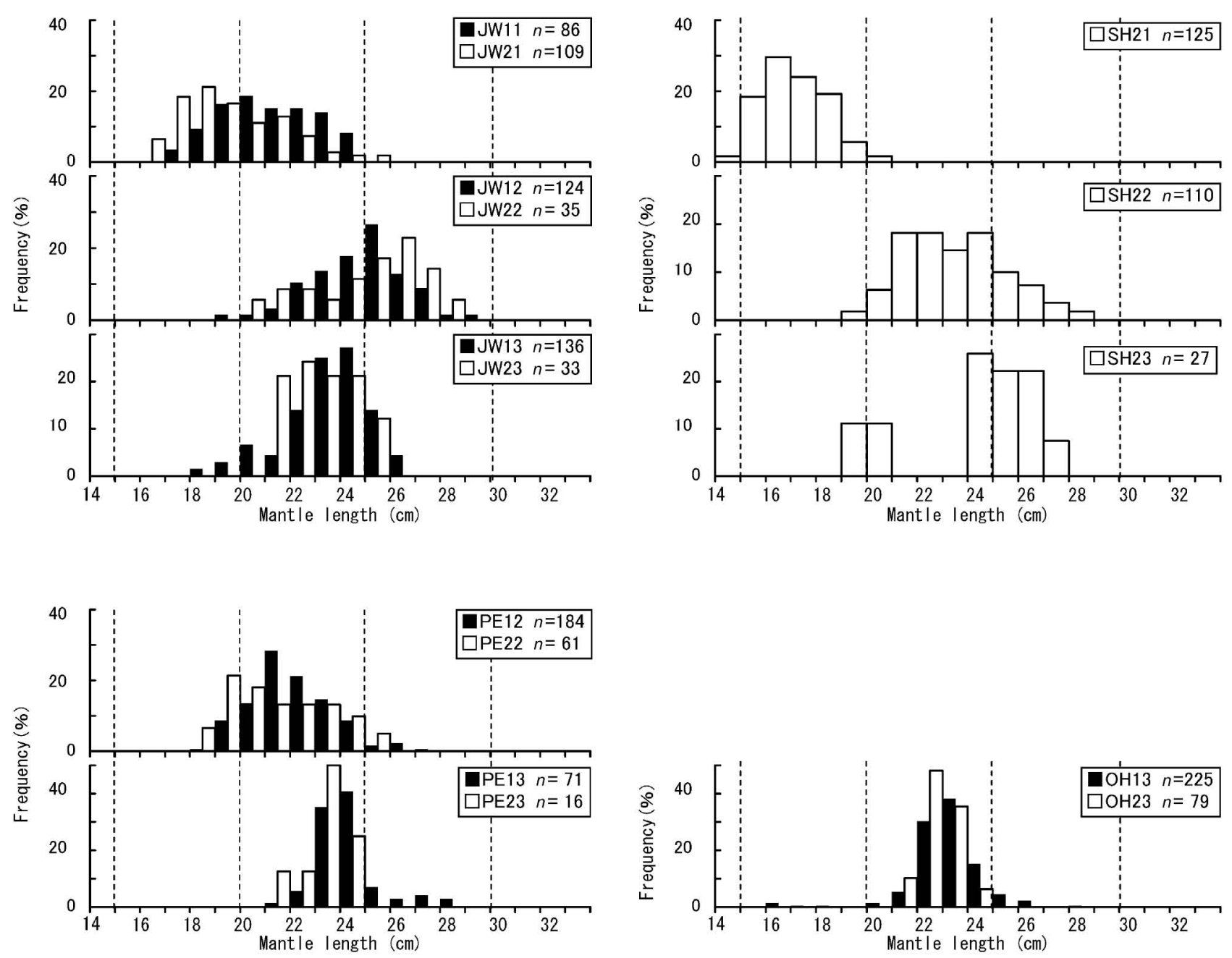

Fig. 2 Length-frequency compositions of each sample group (see Table 1) of age-determined Todarodes pacificus collected in the waters around Hokkaido, 2001 and 2002.

１2 月，8９月採集標本（JW12, JW22）が 12 月で あった。10〜11月採集標本（JW13, JW23）の発生時 期は 12 月〜 6 月で，それ以前に採集した標本より範囲 が広く, 1〜5 月の割合が大きかったが明瞭なピークは みられなかった。採集時期が経過するのに従って発生時 期は遅い時期に変化し, 特に 9 月以前に採集したもの と 10 月以降に採集したもので発生時期は大きく異なっ ていた。2 年間の発生時期の組成は良く似ていたが, 2002 年の $10 \sim 11$ 月採集標本 (JW23) は 2001 年に比 べて 4 5月の比率が高かった。

道南海域で採集したスルメイカの発生時期は， $5 \sim 6$ 月採集標本 $(\mathrm{SH} 21)$ では 11 12 月が主体で, 同時期 の道西日本海と似ていた。8～9 月採集標本 (SH22) の 発生時期には 12 月と 2 月の 2 つのピークがみられた。 10 月採集標本（SH23）の発生時期は 1 5 月で，同時 期の道西日本海と同じく, 範囲が広く明瞭なピークがみ られなかった。
道東太平洋で採集したスルメイカの発生時期は，8～ 9 月採集標本 (PE12, PE22) では $2 \sim 3$ 月が， 10 月採 集標本（PE13, PE23）では 3〜4 月が多かった。2002 年の方が 2001 年よりも発生時期の中心がやや遅い傾向 がみられた。

道東オホーック海で $10 \sim 11$ 月に採集した標本 (OH13, OH23) の発生時期の主体は 3〜4 月であった。 同時期の他の海域と発生時期が重なっていたが，範囲が 狭くまとまっている点と 2002 年の方が 2001 年よりも 発生時期がやや遅い傾向がみられた点で, 道東太平洋と 似ていた。

採集海域別, 時期別に分けた標本グループの主な発生 時期を Table 3 にまとめた。標本グループ別の主な発生 時期から, 北海道周辺海域に分布するスルメイカの発生 時期は, 1 月を境にしてその前の 11〜 12月発生群とそ の後の $2 \sim 5$ 月発生群に分けることができると考えられ た。11 12 月発生群は道西日本海抢よび道南海域で 5 

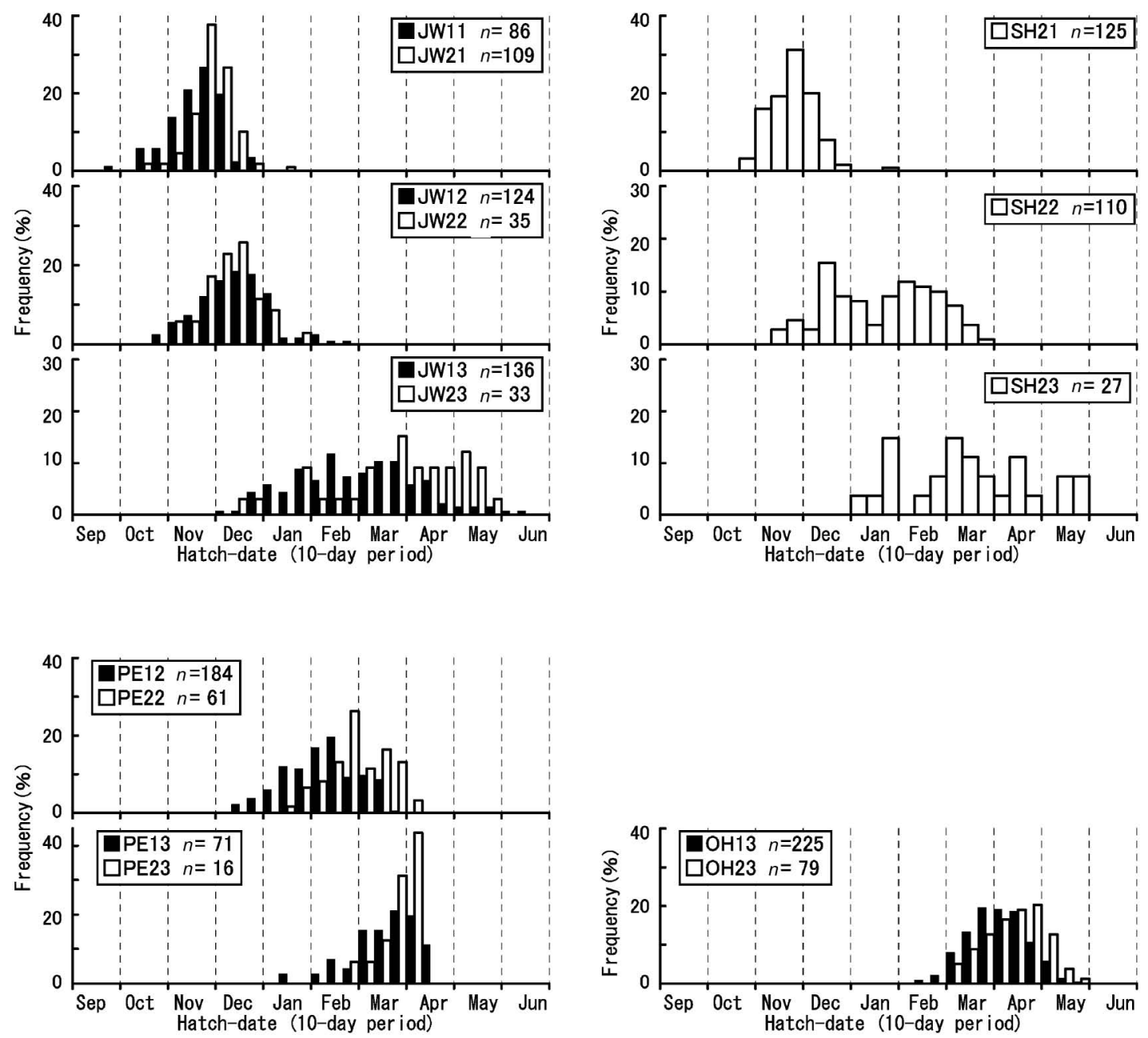

Fig. 3 Hatching date (10-day periods) composition of each sample group (see Table 1) of Todarodes pacificus collected in the waters around Hokkaido, 2001 and 2002.

Table 3 Predominant hatching months of Todarodes pacificus collected in the sampling areas (see Fig. 1) around Hokkaido, 2001 and 2002

\begin{tabular}{|c|c|c|c|}
\hline \multirow{2}{*}{ Sampling area } & \multicolumn{3}{|c|}{ Sampling months } \\
\hline & May-July & August-September & October-November \\
\hline Sea of Japan off Hokkaido (JW) & November to December & December & January to May \\
\hline Waters off southern Hokkaido (SH) & November to December & December and February & January to May \\
\hline Pacific coast off eastern Hokkaido (PE) & & February to March & March to April \\
\hline Okhotsk coast off Hokkaido $(\mathrm{OH})$ & & & March to April \\
\hline
\end{tabular}

～9月に採集された標本に多くみられた。一方，2〜5 月発生群は道南海域抢よび道東太平洋の 8〜10月採集 標本と，道西日本海抢よび道東オホーツク海の $10 \sim 11$ 月採集標本にみられた。2つの発生群の中間の 1 月に発 生したスルメイカは道東オホーツク海以外の各海域にみ られたが，いずれの標本グループでも発生時期の組成の 中心ではなく，その割合は比較的小さかった。道南海域
の 8～9 月採集標本においては， $11 \sim 12$ 月発生群と 2 5 月発生群のスルメイカが混在して多くみられた。

\section{考察}

季節発生群 北海道周辺で採集したスルメイカの発生 時期は 9 月〜翌年 6 月で，いずれの海域でも採集時期 が遅くなるほど, 発生時期も遅れていった。このような 
発生時期の変化は, 早く発生した群が遅い発生群よりも 早く来遊して早く移出することによる分布群の入れ替わ り現象を示していると考えられる。同様の現象は, スル メイカに近縁のアルゼンチンマッイカ（Illex argentinus $)^{14-16)}$ やカナダマッイカ (Illex illecebrosus) $)^{17)}$ でも報告されている。ただし, 本研究では海域によって 発生時期が変化するパターンが異なっており，これには 季節発生群の回遊が影響していると考えられる。

本研究で区分された $11 \sim 12$ 月発生群と $2 \sim 5$ 月発生 群は, それぞれ秋の日本海南西部で生まれ日本海を北上 する秋季発生系群18) と, 冬の東シナ海で生まれ太平洋 と日本海を北上する冬季発生系群 ${ }^{19}$ に対応すると考え られる。したがって，11～12 月発生群（秋季発生系群） は, 日本海を北上し，5９月に道西日本海抢よび道南 海域に来遊したと考えられる。一方，2５月発生群 (冬季発生系群) は, 太平洋もしくは日本海を北上し, $8 \sim 10$ 月に道南海域と道東太平洋に, $10 \sim 11$ 月に道西 日本海と道東オホーツク海に来遊し, 北海道周辺海域に 広く分布したと考えられる。

各海域の発生群 道西日本海の漁期前半の 9 月以前 の分布群が秋季発生系群であったことは, 冬季発生系群 が主体であるとしてきたこれまでの分布特性 ${ }^{20)}$ を修正 した。 これはスルメイカの体サイズが成長の差異の影 響を大きく受けるために, ${ }^{21,22)}$ 体サイズから推定された 日齢が日周輪解析による日齢に修正された結果である。 9 月以前は秋季発生系群の中でゆるやかに群が入れ替わ ったが，10月以降はほとんどが冬季発生系群に入れ替 わり, 体サイズも小さくなった。この冬季発生系群は道 東才ホーック海から回遊してきたものとする考え と, $1,23,24)$ サハリン西方の北部日本海まで北上した冬季 発生系群 ${ }^{25}$ が南下回遊してきたとする考えのほか, 冬 〜春に生まれ日本海を遅れて北上して来遊した可能性も 指摘されている。9 現段階では, 道西日本海の 10 月以降 の分布群はこれらの混合群である可能性が高いと考えら れるが，それぞれの比率など不明な点が多く残されてい る。

道東太平洋には太平洋を北上する冬季発生系群のスル メイカが来遊すると考えられてきた。1,4,26,27) 本研究で も, 道東太平洋には $11 \sim 12$ 月発生群（秋季発生系群） はほとんど確認できず，主に冬季発生系群が分布するこ とが再確認された。

道東オホーツク海には日本海と太平洋の両方からスル メイカが来遊すると考えられてきた。 $23,24,28,29) し か し ，$ この海域の主漁期である 10 11月に採集された標本の 発生時期は道東太平洋の 10 月採集標本と良く似た冬季 発生系群主体の組成であり, 日本海を北上したと考元ら れる 11 12 月発生群（秋季発生系群）はほとんぞ認め られなかった。10)このことは, 日本海から宗谷海峡を経
てオホーツク海に移動するスルメイカは多くないことを 示唆している。したがって, オホーック海の分布群の主 体は太平洋を北上した冬季発生系群が千島列島周辺海域 を経て来遊したものと推察される。

道南海域にも日本海と太平洋の両方加主に冬季発生 系群のスルメイカが来遊すると考えられてきた。1,20,30) しかし, 本研究では, 7 月以前の分布群は日本海を北上 したと考えられる 11 12 月発生群（秋季発生系群）で あったため，これまでの分布特性を修正する。 8〜9月 に採集された標本には, 秋季発生系群の一部と考えられ る 12 月発生群に加えて, 冬季発生系群の一部之考元 れる 2 月前後の発生群も多くみられた。この 2 月前後 の発生群は, 前述の太平洋を北上したと考えられる道東 太平洋の同時期の採集標本と発生時期が一致しており, 同時期の道西日本海の採集標本とは一致しない。さら に, 過去の標識放流調査の結果によると, 青森県および 岩手県の太平洋で放流したスルメイカは, 放流位置から 太平洋を北上して主に 8 月以降に道南海域で再捕され ている。 ${ }^{30-33)}$ 以上のことから, この道南海域の 2 月前後 の発生群は, 太平洋を北上して来遊したことが示唆され る。したがって, 道南海域の 8～9 月のスルメイカは, 主に 12 月に生まれ日本海を北上した秋季発生系群に, 主に 2 月に生まれ太平洋を北上した冬季発生系群が加 入した混合群であると考えられる。この 2 つ発生群 は, 同時期の体サイズの久からでは判別が困難であった。 道南海域の 10 月以降の分布群は, 太平洋を北上した 冬季発生系群が道東太平洋から回遊してきたものと考え られてきた。1,4,30) 他方で, 道西日本海の 10 月以降の分 布群と同様に，冬～春に生まれ対馬暖流の影響を受けて 日本海を遅れて北上したと想定されている冬季発生系 群9)の一部が, 津軽暖流の影響を受けて道南海域にも来 遊した可能性がある。冬に東シナ海で生まれ日本海を北 上する冬季発生系群の分布回遊の情報は少なく, いまだ に不明な点が多く残されているため, 漁況予測や資源評 価の精度を向上させていくうえで, その実態解明が今後 の重要な課題と考えられる。

本研究によって, 北海道周辺海域に抢けるスルメイカ の群構造がより明確になり, 漁況予測や資源評価の精度 が向上することが期待される。

\section{謝辞}

海上調查に協力を頂いた北海道立水産試験場の調查船 金星丸, 打やし抢丸, 北辰丸, 北洋丸, 山形県立加茂水 産高校所属の実習船鳥海丸の乗組員の皆様に打礼申し上 げる。本研究を進めるにあたり, サンプリング作業の協 力や貴重なご意見をいただいたに北海道立水産試験場の 皆さんに打礼申し上げる。最後に, 本研究に取り組む機 会と熱いご指導をいただいた故中田淳氏に感謝する。 


\section{文献}

1）新谷久男.「スルメイカの資源」水産研究叢書. 16 . 日本 水産資源保護協会, 東京. 1967.

2）伊東祐方. 総括 スルメイカの漁業, 生活史および資源の 現状の概要.「スルメイカ漁況予測精度向上のための資源 変動機構に関する研究」農林水産技術会議事務局, 東 京. $1972 ; 4-9$.

3）村田 守, 新谷久男. 北海道北東海域におけるスルメイ 力の生態学的研究 (1968). 北水試研報 1970; 36: 1-17.

4）新谷久男, 村田 守. 北海道東部太平洋域に打けるスル メイカの分布と回遊.「スルメイカ漁況予測精度向上のた めの資源変動機構に関する研究」農林水産技術会議事務 局, 東京. 1972; 95-106.

5）中田 淳. 日本列島大回遊一スルメイカの “系群” と回 遊.「イカの春秋」(奥谷喬司編) 成山堂書店, 東京, 1995; 22-30.

6) Nakamura Y, Sakurai Y. Validation of daily growth increments in statoliths of Japanese common squid Todarodes pacificus. Nippon Suisan Gakkaishi. 1991; 57: 2007-2011.

7）中村好和. 平衡石によるいか類の日齢査定方法.「特定水 産資源評価技術開発調査成果集 1. 小加類，小型浮魚類日 齢査定マニュアル」中央水産研究所, 2000; 1-17.

8) Nakamura Y, Sakurai Y. Age determination from daily growth increments in statoliths of some groups of the Japanese common squid Todarodes pacificus. In Okutani T, O'Dor RK, Kubodera T (eds) Recent Advances in Cephalopod Fisheries Biology. Tokai University Press, Tokyo. 1993; 337-342.

9）坂口健司, 中田 淳. 2001 年の北海道北部海域における スルメイカの日齢と群構造. 水産海洋研究 2006; 70: 16 -22 .

10）佐藤 充, 坂口健司. 2001 ・2002 年に北海道オホーツク 海沿岸海域へ来遊したスルメイカの発生時期について. 北水試研報 2007; 72: 9-13.

11）中田 淳. 平衡石日齢查定による道南日本海のスルメイ 力の発生時期の推定 (予報). イ力類資源 - 漁海況検討会 議研究報告 (平成 4 年度), 遠洋水産研究所. 1994; 111.

12) Jackson GD. Application and future potential of statolith increment analysis in squids and sepioids. Can. J. Fish. Aquat. Sci. 1994; 51: 2612-2625.

13）坂口健司. スルメイカの平衡石の採取および輪紋計数マ 二ュアル. 技術資料 No. 4. 北海道立釧路水産試験場. 2005.

14) Arkhipkin AI. Age, growth, stock structure and migratory rate of pre-spawning short-finned squid Illex argentinus based on statolith ageing investigations. Fish. Res. 1993; 16: $313-338$.

15) Arkhipkin AI. Intrapopulation structure of winter spawned Argentine shortfin squid, Illex argentinus (Cephalopoda, Ommastrephidaea), during its feeding period over the Patagonian Shelf. Fish. Bull. 1999; 98: 113.

16) Uozumi Y, Shiba C. Growth and age composition of Illex argentinus (Cephalopoda: Oegopsida) based on daily increment counts in statoliths. In Okutani T, O'Dor RK, Kubodera T (eds) Recent Advances in Cephalopod Fisheries Biology. Tokai University Press, Tokyo. 1993; 591-
605.

17) Dawe EG, Beck PC. Population structure, growth, and sexual maturation of short-finned squid (Illex illecebrosus) at Newfoundland. Can. J. Fish. Aquat. Sci. 1997; 54: 137146.

18）木所英昭, 後藤常夫, 田永 軍. 平成 19 年度スルメイ 力秋季発生系群の資源評価. 平成 19 年度我が国周辺水 域の漁業資源評価（漁種別系群別資源評価・TAC 種）第 1 分冊, 水産庁増殖推進部, 独立行政法人水産総合研究 センター, 東京. 2008; 529-560.

19）森賢, 永澤 亨. 平成 19 年度スルメイカ冬季発生 系群の資源評価. 平成 19 年度我が国周辺水域の漁業資 源評価（漁種別系群別資源評価・TAC 種）第 1 分冊, 水産庁増殖推進部, 独立行政法人水産総合研究セン ター，東京. 2008; 497-528.

20）新谷久男, 石井 正. 北海道周辺海域に打けるスルメイ 力の系統群.「スルメイカ漁況予測精度向上のための資源 変動機構に関する研究」農林水産技術会議事務局, 東京. 1972; 192-205.

21）木所英昭, 檜山義明. 日本海におけるスルメイカの分布 海域による成長の差異. 日水研報 1996; 46: 77-86.

22）坂口健司, 高柳志朗. 1996, 1997 年で道西日本海におけ るスルメイカの体サイズが異なった要因. 北水試研報 2001; 59: 25-30.

23）中村好和, 森 賢. 1996 年の道東 - 南部千島太平洋並 びにオホーツク海でのスルメイカとアカイカの分布と回 遊. 北水試研報 1998; 62: 63-82.

24）森 賢, 中村好和. 標識放流から推定したスルメイカ 太平洋系群の回遊経路. 北水試研報 2001; 65: 21-43.

25）新谷久男, 加賀吉栄. 北部日本海海域におけるスルメイ 力の分布と回遊.「スルメイカ漁況予測精度向上のための 資源変動機構に関する研究」農林水産技術会議事務局, 東京. 1972; 144-153.

26）森 賢, 中村好和. 黒潮親潮移行域周辺に打けるスル メイカ幼体の分布. 日水誌 $2003 ; \mathbf{6 9 :} 23-29$.

27) Kawabata A, Yatsu A, Ueno Y, Suyama S, Kurita Y. Spatial distribution of the Japanese common squid, Todarodes pacificus, during its northward migration in the western North Pacific Ocean. Fish. Oceanogr. 2006; 15: 113-124.

28）村上幸一. 南部千島海域におけるスルメイカの分布と移 動について. 北水試月報 $1970 ; 27: 204-215$.

29）新谷久男，村田 守. オホーツク海域におけるスルメイ 力の分布と回遊.「スルメイカ漁況予測精度向上のための 資源変動機構に関する研究」農林水産技術会議事務局, 東京. 1972; 107-114.

30）安井達夫, 久保田清吾, 橋場敏雄, 斉藤重男, 湊 栄 一, 松井 勇. 東北・北海道太平洋側海域におけるスル メイカの分布と回遊.「スルメイカ漁況予測精度向上のた めの資源変動機構に関する研究」農林水産技術会議事務 局, 東京, 1972; 68-94.

31） 赤羽光秋, 久保田清吾. 東北海区沖合に打ける夏季のス ルメイカの漁場形成と回遊について. 東北水研報 1972; 32: 47-58.

32）田村真通. 東北海区におけるスルメイカ沖合回遊経路に ついて. 月刊海洋科学 $1984 ;$ 16: 12: 702-706.

33）阿部繁弘. 1984 年夏季における東北海区沖合から岩手県 沿岸へのスルメイカの加入について．イカ類資源・漁海 況検討会議研究報告 (昭和 59 年度), 北海道区水産研究 所. $1985 ; 45-54$. 